\title{
Gary M. Gartsmann: Shoulder arthroscopy second edition + DVD
}

\section{Saunders Elsevier, Philadelphia, 2009, 380 pp, num figs. Hardcover XXX US \$, ISBN 978-1416046493}

\author{
Pierre Kehr
}

Received: 15 August 2009 / Accepted: 18 August 2009 / Published online: 17 September 2009

(C) Springer-Verlag 2009

Since the first edition the arthroscopic techniques have improved, and this book gives a progress report on the actual position of this science.

The first part relates to the phase of step by step training of the shoulder arthroscopy.

The second and third parts relate to, respectively, the shoulder joint and the subscapularis space.

The large iconography available and the DVD with live recordings of the techniques, are the main attractions of this book.
This book will interest the beginner surgeon as well beginning as the experienced surgeons seeking to improve their technique or to learn from new indications.

No funds were received in support of this study.

Alain Graftiaux

P. Kehr $(\bowtie)$

Strasbourg, France

e-mail: kehrpier@aol.com 